\title{
Distribution of Two Species of Curly-tailed Lizards, Genus Leiocephalus, in a Metropolitan Park, and the Rediscovery of a Nominate Subspecies
}

\author{
Miguel A. Landestoy T. and Francis O. Reyes \\ Escuela de Biología, Universidad Autónoma de Santo Domingo, República Dominicana (hispanioland@gmail.com)
}

Photographs by the senior author.

\begin{abstract}
Two Hispaniolan endemic species of lizards in the genus Leiocephalus (L. lunatus Cochran 1934 and $L$. personatus Cope 1862) are parapatric in an urban park in Santo Domingo, capital of the Dominican Republic. In the course of this study, we unexpectedly rediscovered the long-overlooked nominate subspecies of Leiocephalus lunatus 1 $\mathrm{km}$ inland from the vicinity of the type locality as what appears to be a relict population. Two congeners in the same urban setting within their natural ranges is an uncommon scenario. We provide detailed distributional data for both species within the Parque Mirador del Sur, and also report surviving populations of $L$. l. lunatus west of its type locality.
\end{abstract}

$\mathrm{T}$ The genus Leiocephalus (monotypic family Leiocephalidae) comprises 23 extant species on Cuba, Hispaniola, the Bahamian Archipelago, and the Cayman Islands (Hedges 2018). Hispaniola supports the greatest diversity, with 12 species endemic either to the main island or one of its satellites (i.e., Isla Alto Velo and Île de La Gonâve). Commonly referred to as "curlytails" or "curly-tailed lizards," these are diurnally active terrestrial lizards that occur primarily in lowland areas. At least four species have been reported to inhabit urban environments (e.g., Rodríguez Schettino et al. 1999; Powell and Henderson 2008; Henderson and Powell 2009). This is the first reported instance on Hispaniola, where two species occur in close proximity and are nearly sympatric in an urban setting.

One species, the Hispaniolan Maskless Curly-tailed Lizard (L. lunatus; Fig. 1), with six described subspecies (Powell and Gifford 2010), is largely restricted to an inland "linear-coastal" distance of $40 \mathrm{~m}$ (Gali and Schwartz 1982) on seaside limestone bedrock and beaches of the coastal plains in the southeastern Dominican Republic and several neighboring satellite islands (islas Catalina, Catalinita, and Saona). Another species, the Hispaniolan Masked Curlytailed Lizard (L. personatus; Fig. 2), with 12 recognized subspecies (Henderson and Powell 2009), is widely distributed, mostly in well-shaded habitats of the interior, although at times in coastal areas where L. lunatus is absent (Schwartz 1969; Schwartz and Henderson 1991). Of the two taxa known to occur in the capital, L. p. trujilloensis Mertens
1939 is restricted to the south-central Dominican lowlands, whereas the nominate subspecies of the other, L. lunatus lunatus, has been known only from the coastal western parts of the greater Santo Domingo area (the Distrito Nacional and Santo Domingo Oeste Province).

\section{Materials and Methods}

The Parque Mirador del Sur (Fig. 3) is an elongated green space with a relatively continuous canopy. It is approximately $6 \mathrm{~km}$ in length and averages roughly $200 \mathrm{~m}$ in width (in a northeast to southwest orientation), with the narrowest point at its eastern terminus (to the Avenida Jiménez Moya). The nearly continuous park is dissected only by the Avenida Italia and partially by the Calle Pedro A. Bobea.

We (generally two observers) searched for lizards on various days and at times when curlytails are known to be active (see below) from 11 May to 28 August 2017, walking sections ranging from 1 to $2.5 \mathrm{~km}$ in length, but not necessarily in straight lines. Although we usually followed paths or sidewalks, we ventured into the park in order to cover as much of the terrain as possible. We recorded more than $90 \%$ of the tracks walked and took coordinates using a GPS portable unit (Garmin GPSMAP 64s) and/or a cellphone. In addition, from 24 May to 8 September 2017, we surveyed (usually only one observer) the long stretch of coastline (the Malecón) that should comprise the imprecise type locality of L. lunatus, essentially the entire coast of the Distrito Nacional 


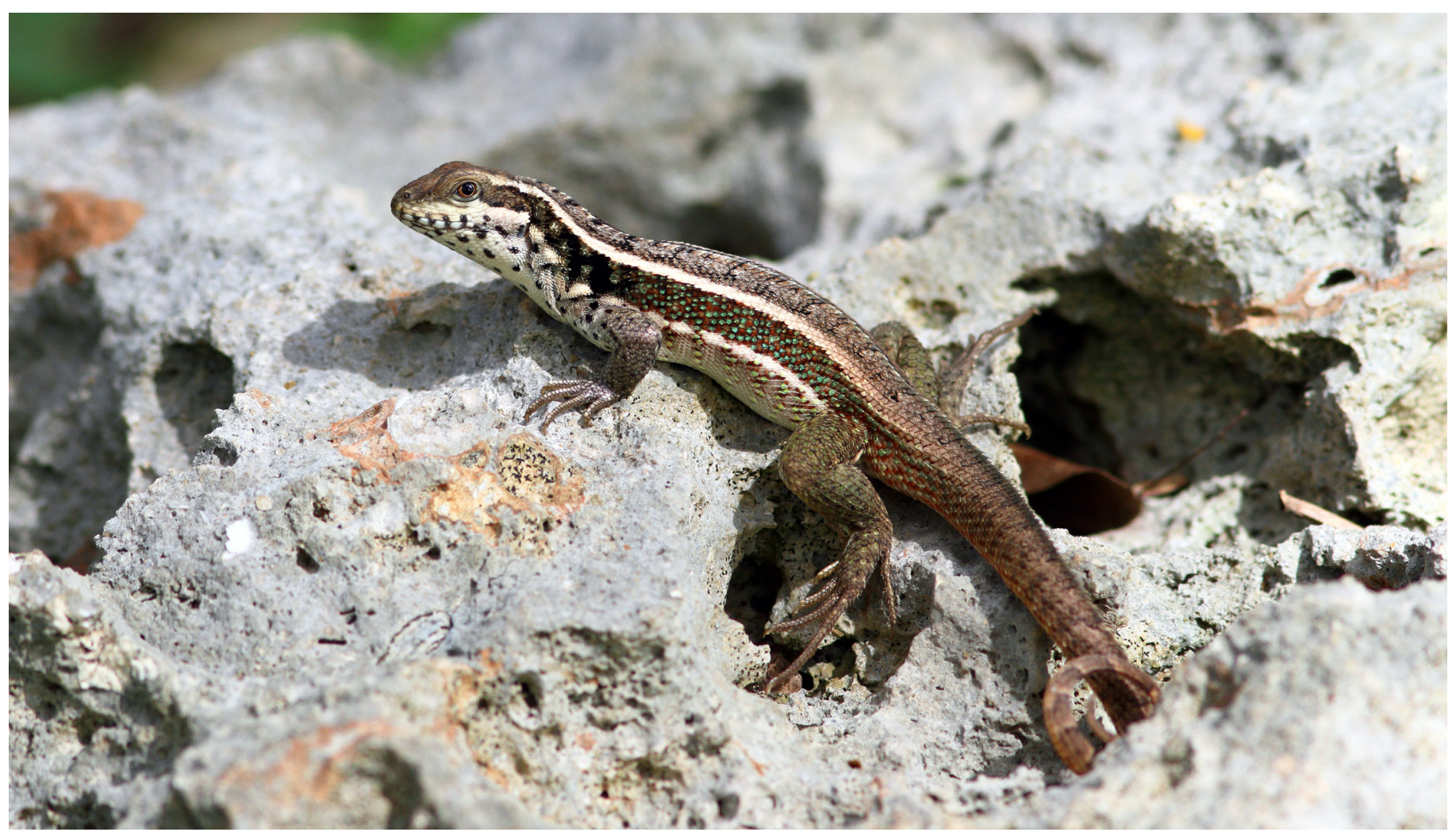

Fig. 1. An adult male Hispaniolan Maskless Curly-tailed Lizard, Leiocephalus lunatus lunatus (Harvard University Museum of Comparative Zoology Herpetology Observation 40), from the Parque Mirador del Sur, Distrito Nacional, Dominican Republic.

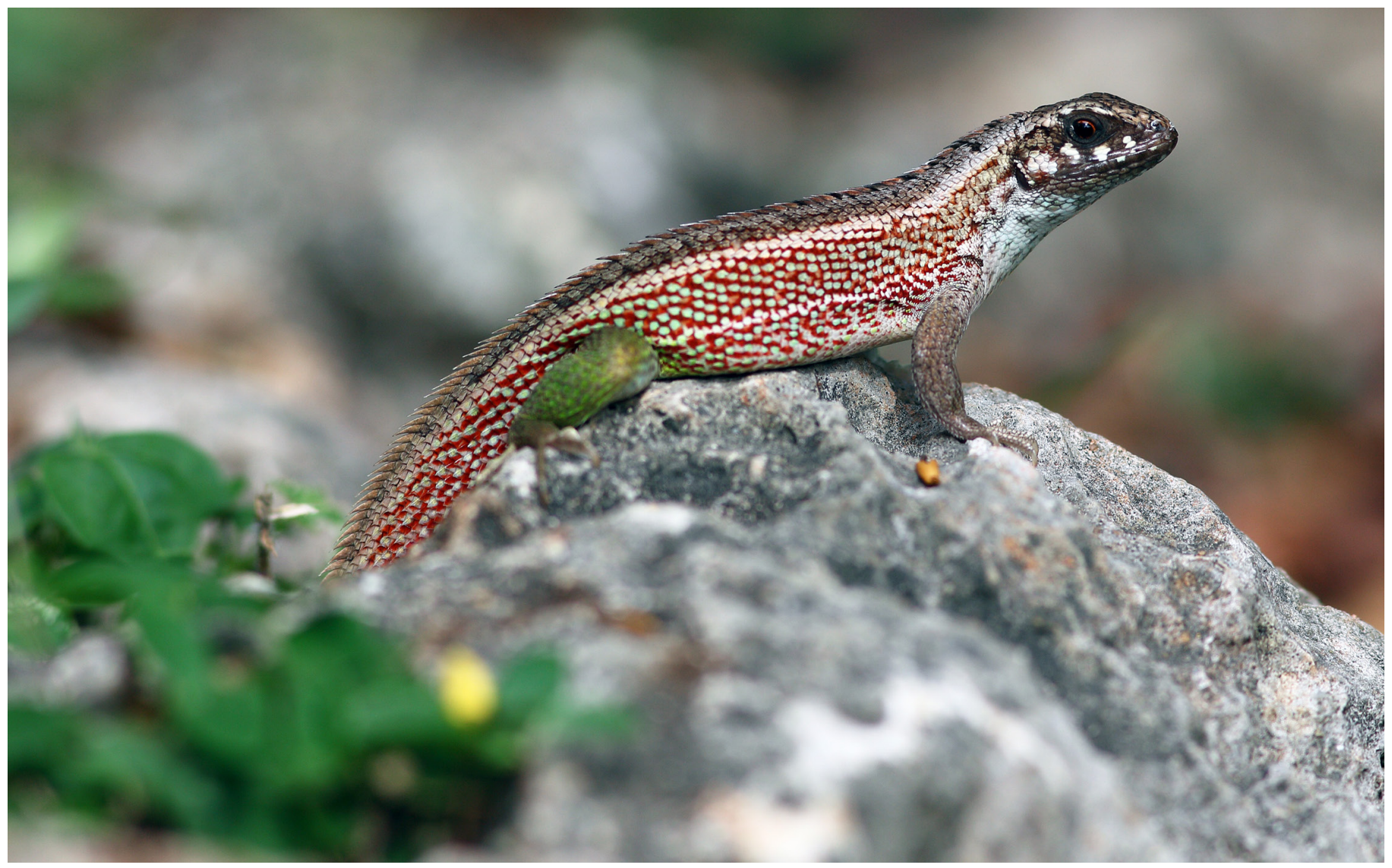

Fig. 2. An adult male Hispaniolan Masked Curly-tailed Lizard, Leiocephalus personatus trujilloensis (Harvard University Museum of Comparative Zoology Herpetology Observation 43), from the Parque Mirador del Sur, Distrito Nacional, Dominican Republic. 


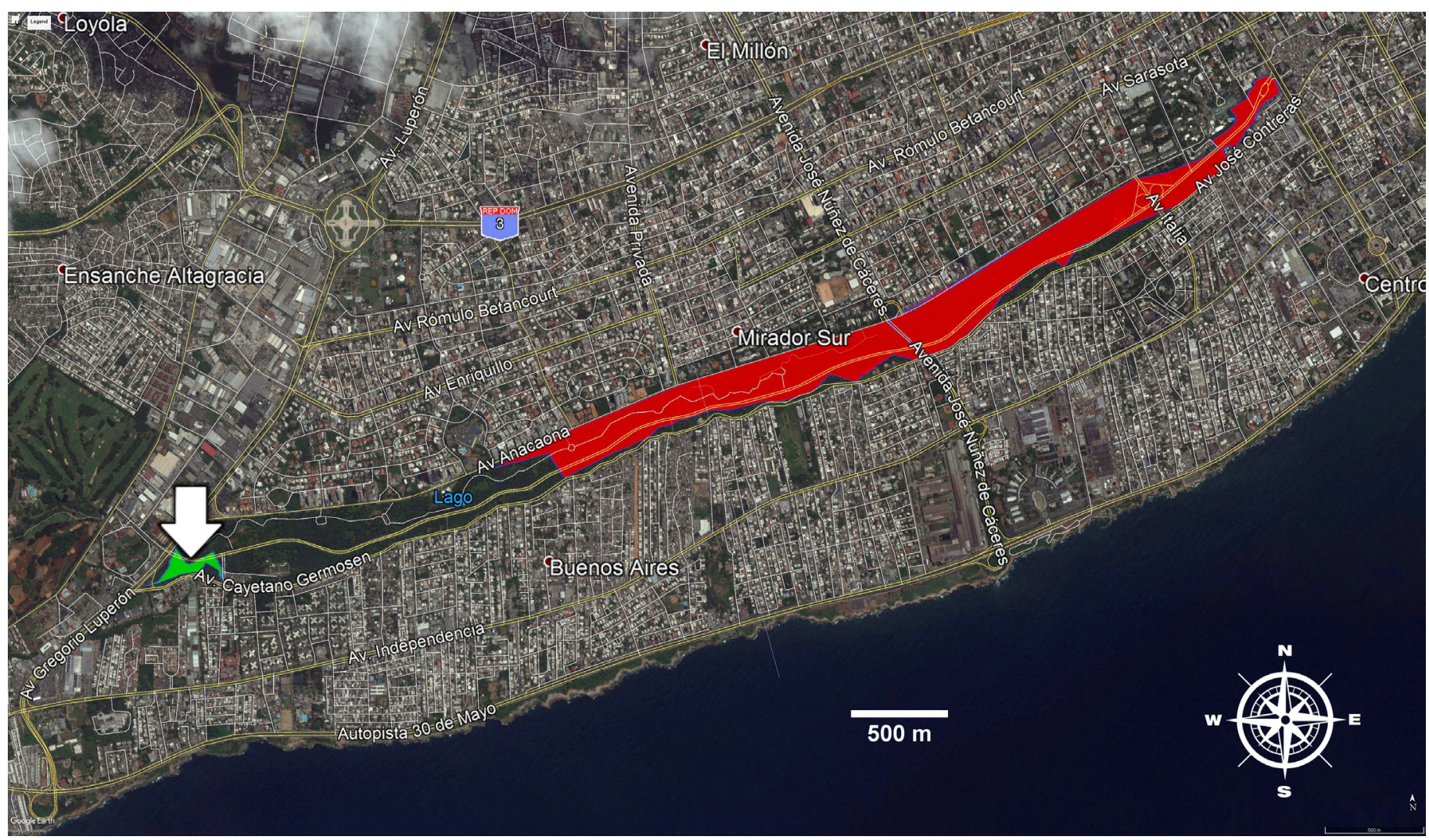

Fig. 3. Parque Mirador del Sur in the Distrito Nacional, Santo Domingo, showing the parapatric distribution of the two species of Leiocephalus found in the park. The red polygon represents the distribution of $L$. personatus trujilloensis in the park, whereas the green polygon in the southwestern corner of the park represents that of L. l. lunatus. Adapted from a Google Earth ${ }^{\circledR}$ image.

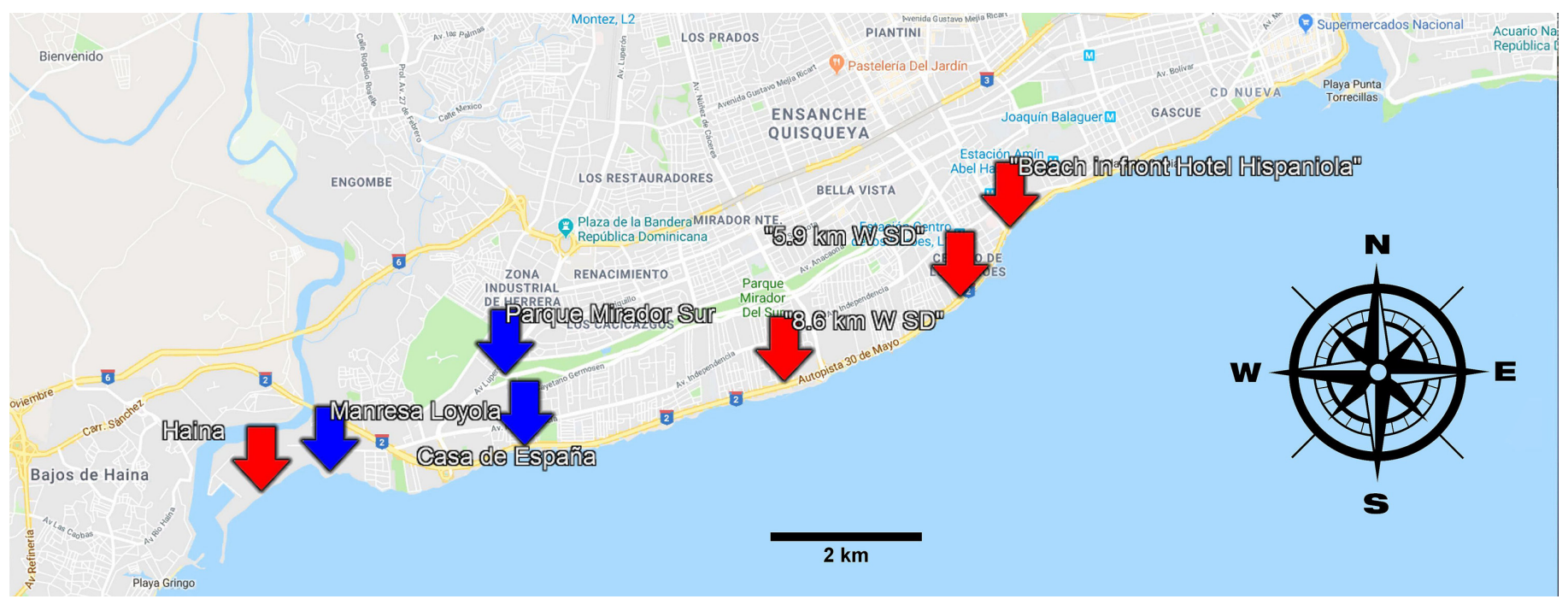

Fig. 4. The Distrito Nacional and Santo Domingo Oeste between the Río Haina and Río Ozama showing recent and historical sites where Leiocephalus lunatus lunatus was encountered. Blue arrows mark the sites where populations were found during this study: (1) Parque Mirador del Sur, $1 \mathrm{~km}$ inland from the vicinity of the type locality (the Malecón; see also Fig. 3); (2) the coast at Manresa Loyola $\left(18.42344^{\circ} \mathrm{N}, 70.00358^{\circ} \mathrm{W}\right)$; and (3) the coast in front of the Parque Atlántida and Casa de España $\left(18.42638^{\circ} \mathrm{N}, 69.98007^{\circ} \mathrm{W}\right.$ ). Red arrows mark historical sites (Schwartz 1969). The actual type locality is too imprecise to plot. Adapted from Google Maps ${ }^{\odot}$.

along the Avenida Francisco A. Caamaño (or its continuation, the "Avenida del Puerto"), Avenidas 30 de Mayo and George Washington, and to the Avenida Prolongación Independencia to the mouth of Río Haina in Santo Domingo Oeste Province (Fig. 4). We measured straight-line distances using the ruler tool of Google Earth ${ }^{\odot}$, except for historical localities for which we employed a vehicle's odometer (presumably mimicking the methods used by Schwartz 1967, 1969).

At the Parque Mirador del Sur, we revisited at least twice all areas in which we failed to detect any curlytails within 


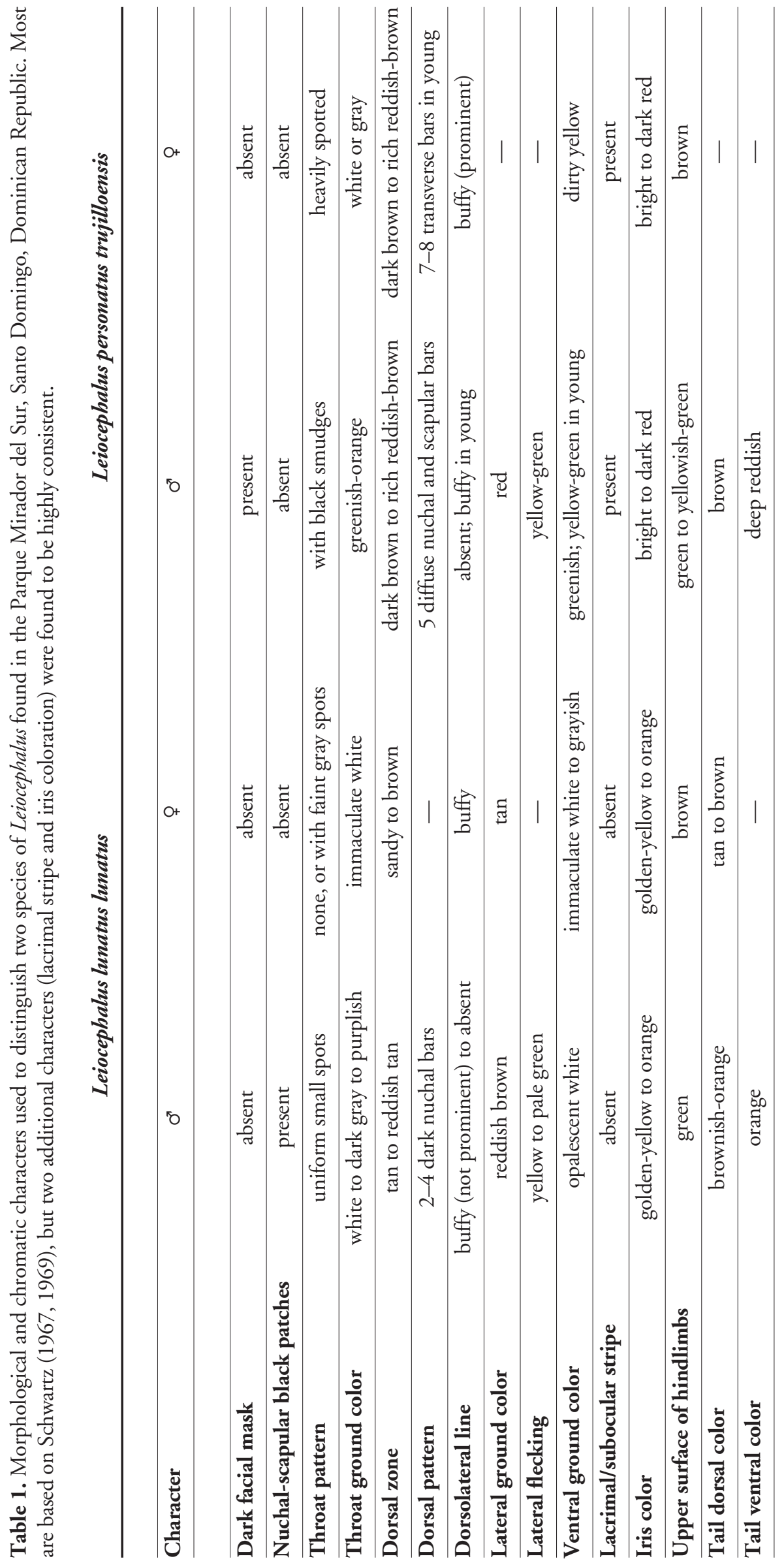


approximately $200 \mathrm{~m}$. For surveys along the type locality of L. l. lunatus, we used known activity patterns of the neighboring subspecies (L. l. lewisi) and data generated during this study to conduct searches during hours of known activity. Generally, we preferred mid-afternoon hours during favorable, sunny weather conditions.

We photographed many lizards using a cellphone to obtain the coordinates from the metadata, but also used Canon EOS 7D, 5D MKII and Powershot G15 cameras to record high-resolution images that could be used as vouch- ers and to confirm the identity of individuals. Also, to assure proper identification, we used binoculars, descriptions and illustrations from the literature, and an image bank generated since we initiated surveys. Table 1 lists morphological and chromatic characters from the literature and two additional characters (see below) that we consider relevant in distinguishing the two species.

Especially the males of the two species differ from each other in size as well as in several external characters (Table 1). Male L. lunatus (Figs. $1 \& 5$ ) are smaller, reported by Powell

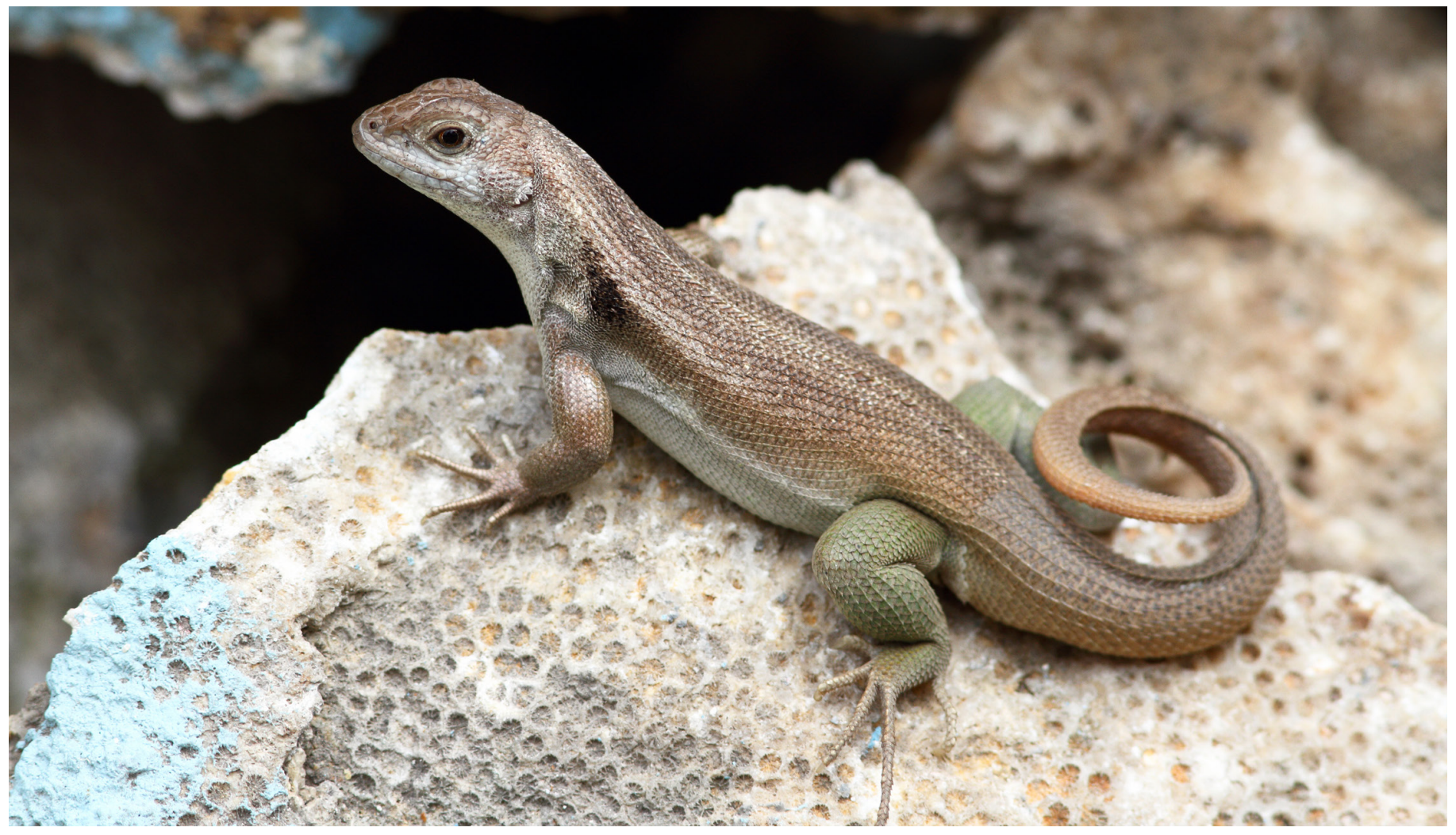

Fig. 5. An adult male Leiocephalus lunatus lunatus (Harvard University Museum of Comparative Zoology Herpetology Observation 39) with an unusual pattern, lacking the throat spots and having a small, single nuchal-shoulder patch. Note that the sides lack defined lines and vivid coloration.
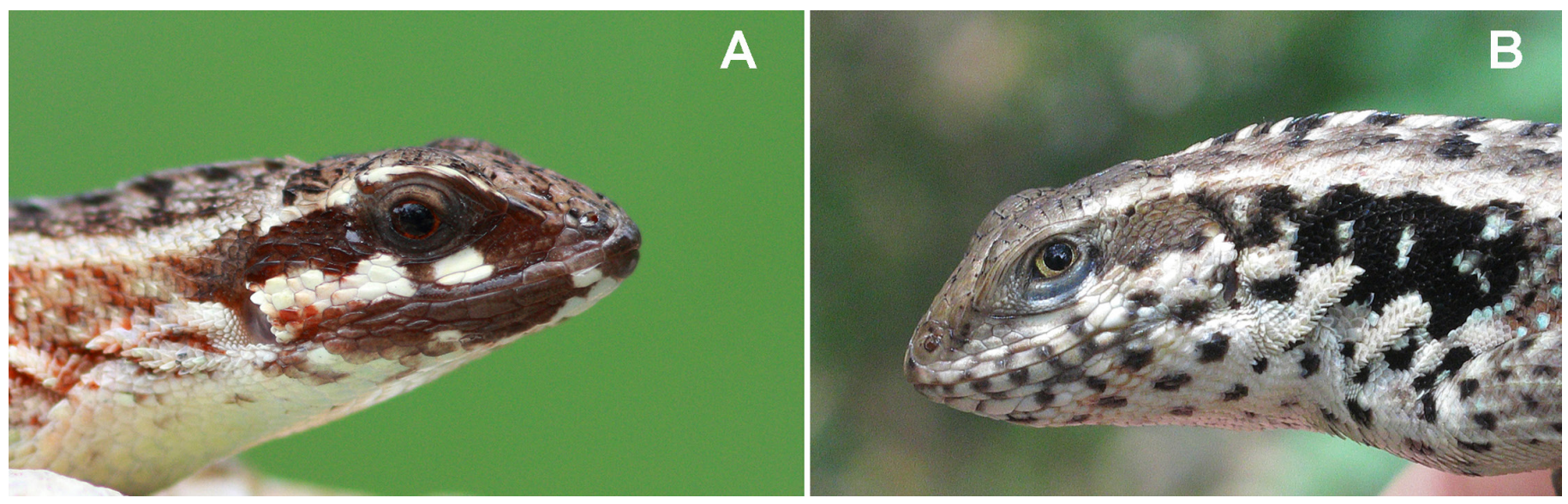

Fig. 6. Heads of adult male Leiocephalus lizards from the Parque Mirador del Sur: (A) L. personatus trujilloensis (Harvard University Museum of Comparative Zoology Herpetology Observation 41) with mask and lacrimal stripe, and (B) L. lunatus lunatus (Harvard University Museum of Comparative Zoology Herpetology Observation 36). Note the color of the irises. 


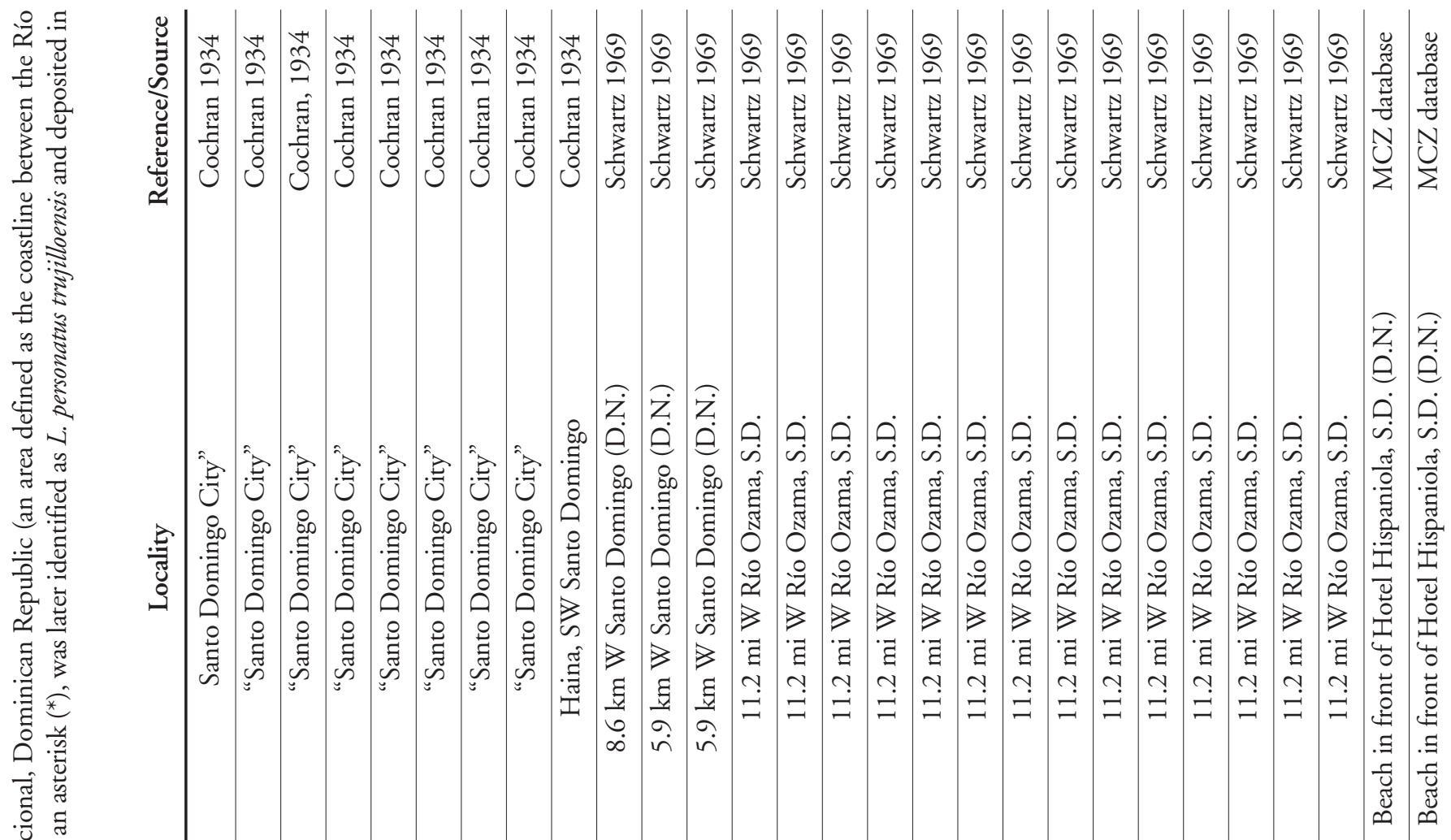

乙

.

营

\&is

घี

คับ

藏 $\sum_{1}$

กี

$\exists$ चี

के

8 亏

竎

要

z

空

3

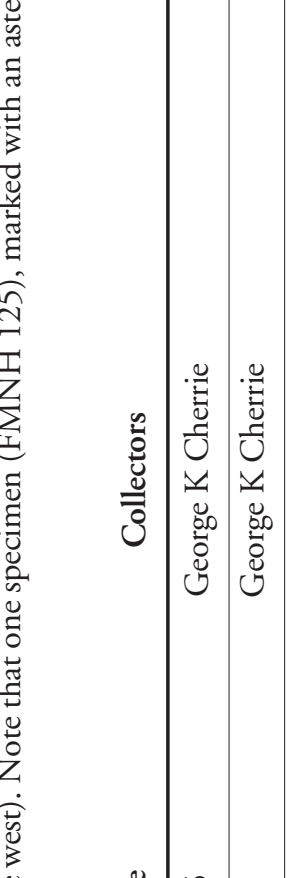

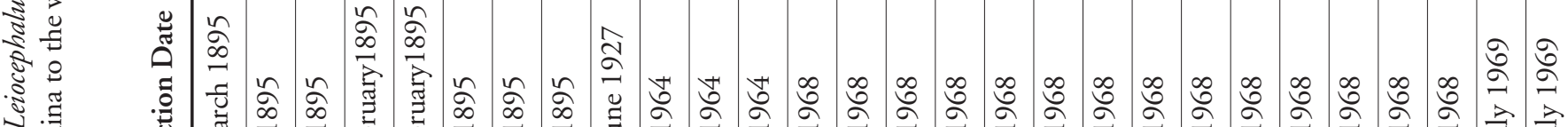

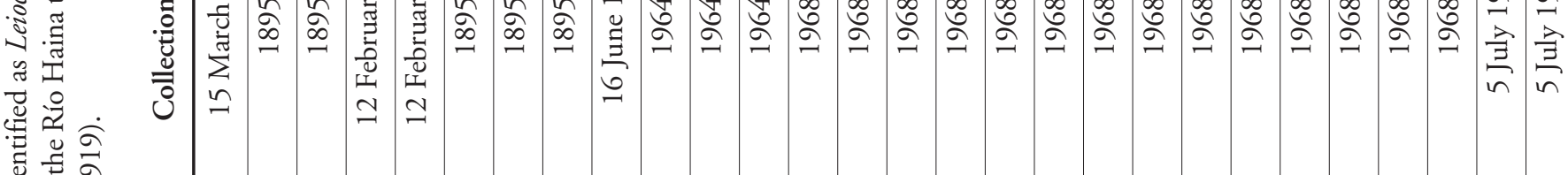
苛 है थे

范

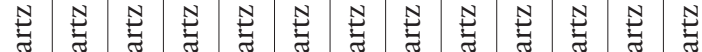

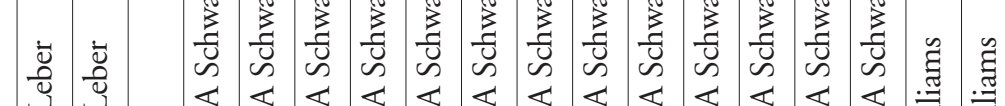

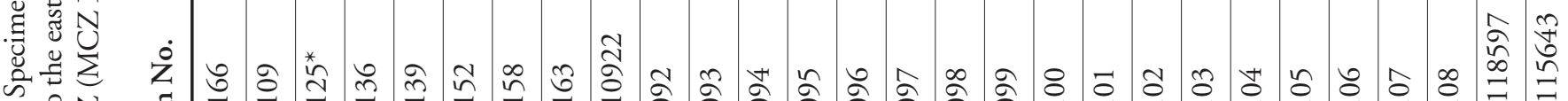

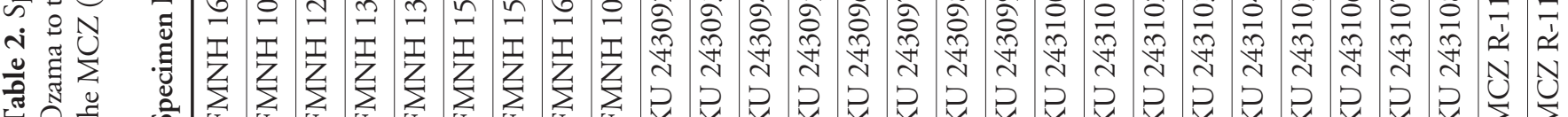

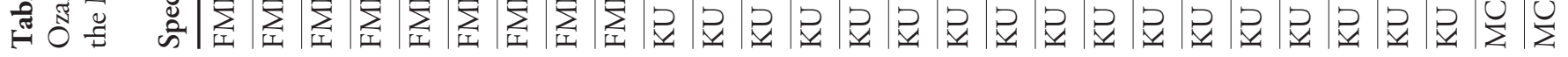


and Gifford (2010) to reach a maximum snout-vent length (SVL) of $67 \mathrm{~mm}$, whereas male L. personatus (Fig. 2) can reach $86 \mathrm{~mm}$ SVL (Henderson and Powell 2009), although Mertens (1939) recorded a maximum SVL of $78 \mathrm{~mm}$ for L. $p$. trujilloensis. The estimated size (SVL) at which females reach maturity is $46.5 \mathrm{~mm}$ for L. lunatus and $42.5 \mathrm{~mm}$ for L. personatus (Gifford and Powell 2007).

Male L. lunatus typically have several parallel nuchalshoulder patches (the "crescentic sepia markings" of Cochran 1934), which are black in life and in most preserved specimens (e.g., MCZ 115643, 118597; Table 2), and in specimens of other L. lunatus subspecies (L. l. louisae, MNHNSD 23.152, 23.626-7; L. l. arenicolor, MCZ 158229; L. l. melaenascelis, MNHNSD 23.607-9, 23.616, 23.621-2; collected in 1974, 1979, and 1981, respectively). The patches in a few specimens (e.g., MNHNSD 23.157, 23.211; collected in 1974 and 1984, respectively) are brownish instead of black. Males of $L$. personatus lack those patches and have a characteristic dark brown to black mask (Figs. $1 \&$ 6A). Throats in male L. lunatus (Figs. $7 \& 8 \mathrm{~B}$ ) typically have large, moreor-less uniformly-sized black spots on a white or pale gray ground color that extends onto the chest, whereas the throat in male $L$. personatus varies from solid black to uniform yellow, although some subspecies have a few scattered and diffuse spots (not bold and evenly distributed as in L. lunatus). Neither male nor female $L$. lunatus have a ventral pattern, whereas female $L$. personatus bear spots covering the entire venter and throat (the throat in female L. lunatus lunatus is immaculate white, at times faintly spotted with very pale gray; Schwartz 1967, 1969). The latter is the most conspicuous character when comparing females of the two species (Figs. 9-10; Table 1). Juveniles of both species resemble females.

Female L. p. trujilloensis from the Parque Mirador del Sur bear bold, dark lacrimal stripes that usually begin at the lower edges of the eyes and extend across the subocular scales to the adjoining supralabial scales (Fig. 9). Male and female L. l. lunatus from the park lack this stripe (Figs. 6B, 7A-C, 9), and we have seen only one male of this species with some faint pigmentation in the area (Fig. 7C). That agrees with Cochran (1934), who noted that the infraocular region is usually pale (e.g., Fig. 7B). In addition to the lacrimal stripe, we add another character, the color of the iris. This character
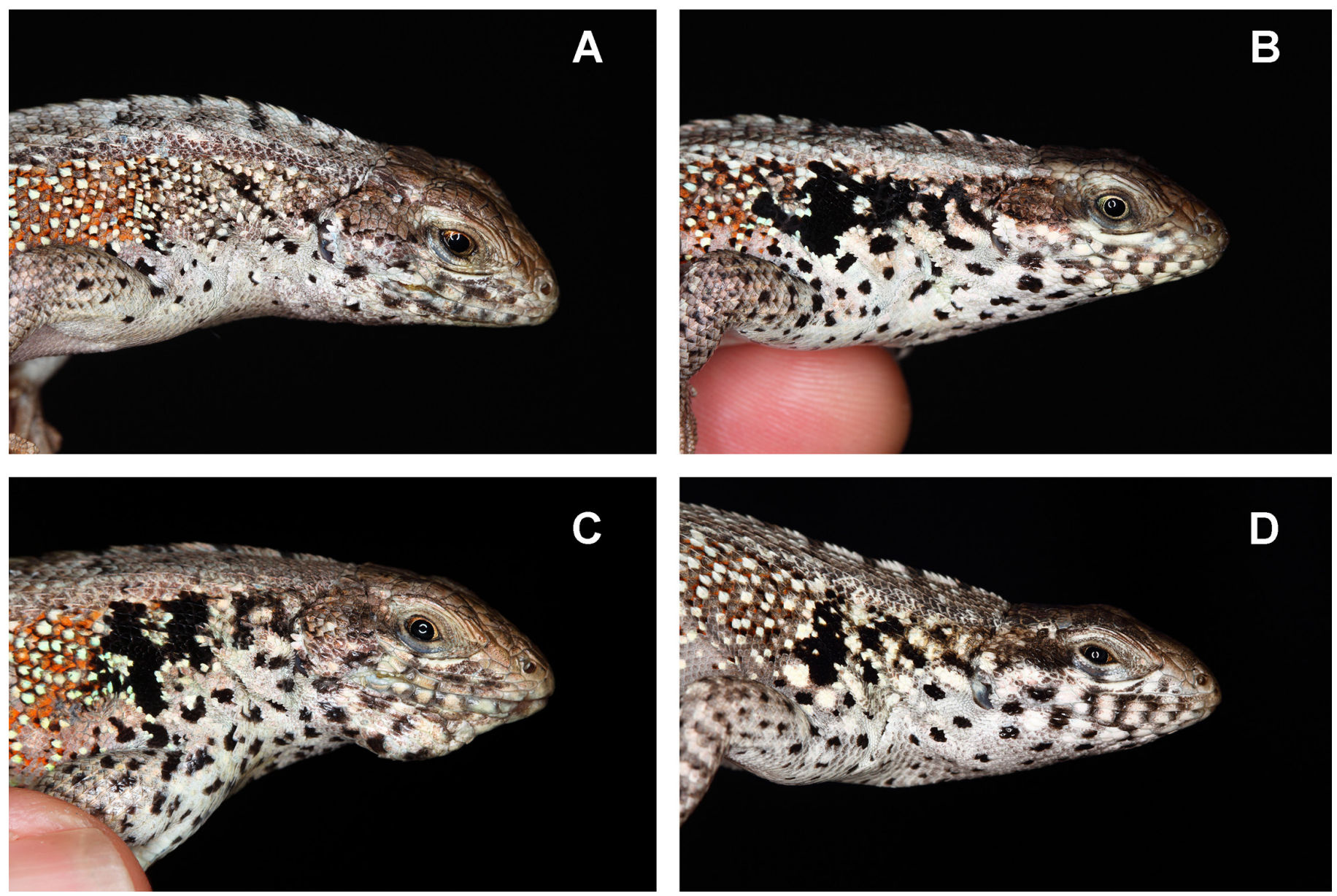

Fig. 7. Lateral views of heads of adult male Leiocephalus lunatus lunatus: (A) Harvard University Museum of Comparative Zoology Herpetology Observation 33, (B) Harvard University Museum of Comparative Zoology Herpetology Observation 34, and (C) Harvard University Museum of Comparative Zoology Herpetology Observation 35 from the Parque Mirador del Sur, whereas (D) Harvard University Museum of Comparative Zoology Herpetology Observation 37 is from the vicinity of the type locality. 


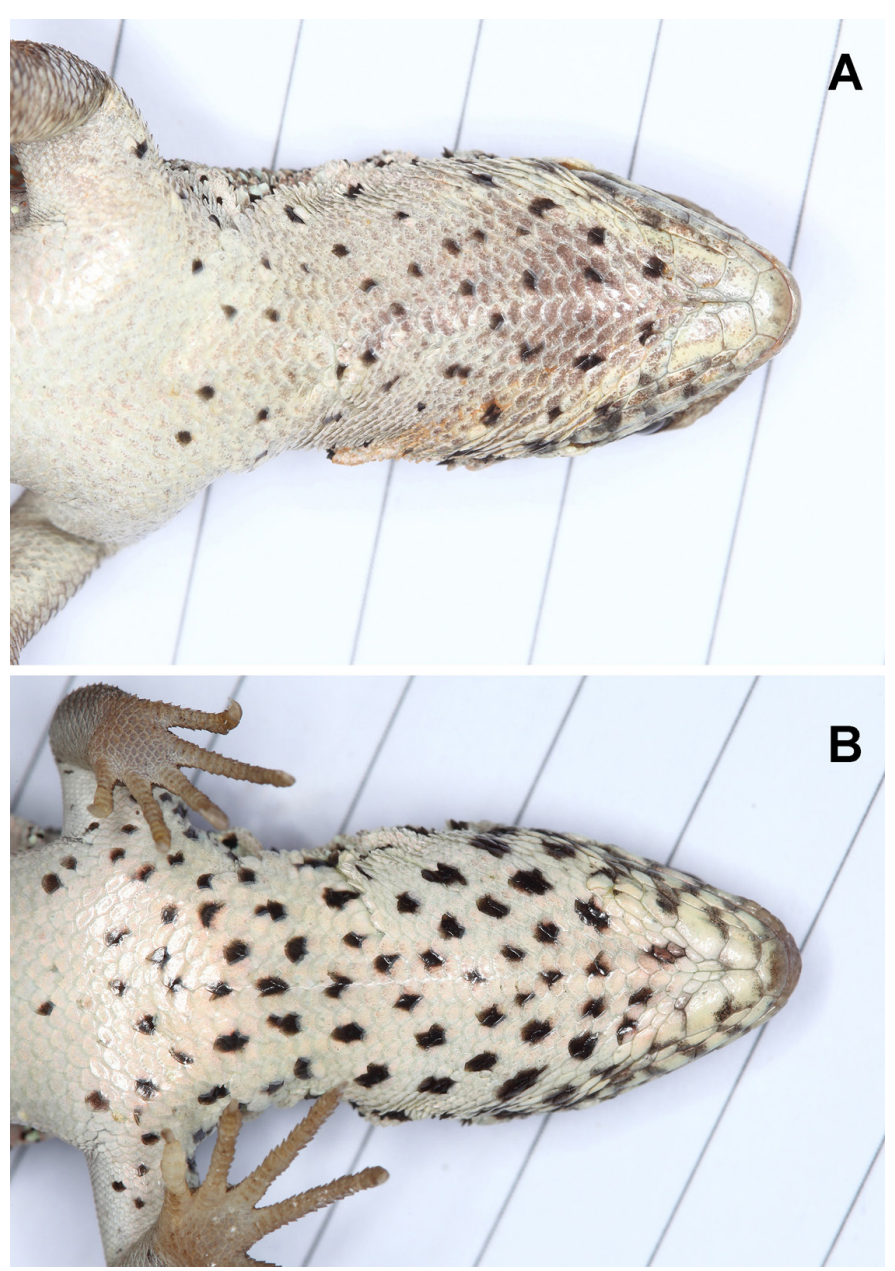

Fig. 8. Variation in spot patterns on the throats of male Leiocephalus lunatus lunatus: (A) Harvard University Museum of Comparative Zoology Herpetology Observation 34 with small and widely spaced spots evident even after metachrosis (Fig. 11), and (B) Harvard University Museum of Comparative Zoology Herpetology Observation 34 exhibiting a more usual spotting pattern.

was not cited until used recently by Köhler et al. (2016) in the description of a new Hispaniolan species of Leiocephalus. Earlier collectors most likely did not record iris coloration from live individuals, and specimens would tend to lose the natural pigmentation after preservation. Rodríguez Schettino (1999) did note iris coloration for five of six Cuban species. All of the adult $L$. l. lunatus that we photographed had a golden-yellow or orangish iris color (Fig. 6B), whereas that of L. p. trujilloensis was bright red (Fig. 6A). We do not know if this character changes with ontogeny.

We measured live individuals to the nearest $0.1 \mathrm{~mm}$ using a digital caliper before releasing them near original capture sites. Because we have not determined the size of the populations (especially those of $L$. l. lunatus), we did not collect any specimens. Institutional codes and place names are abbreviated as follows: Museo Nacional de Historia Natural de Santo Domingo (MNHNSD), Museum of Comparative Zoology (MCZ), photographic vouchers of herpetological observations in the MCZ collection (Harvard University Museum of

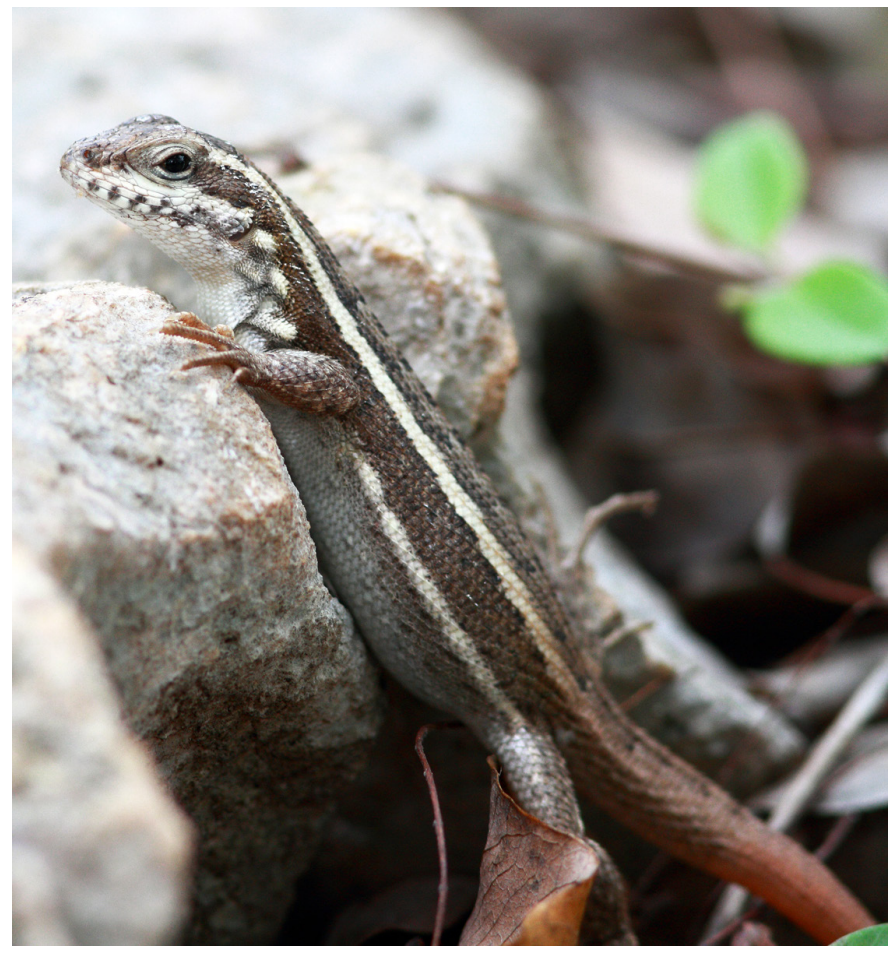

Fig. 9. An adult female Leiocephalus lunatus lunatus (Harvard University Museum of Comparative Zoology Herpetology Observation 38) without spots on the throat and venter.

Comparative Zoology Herpetology Observations), University of Kansas Museum of Natural History (KU), Field Museum of Natural History (FMNH), Santo Domingo (S.D.), and Distrito Nacional (D.N.).

\section{Results and Discussion}

Observations.-One unusual male L. l. lunatus (Harvard University Museum of Comparative Zoology Herpetology Observation 39, Fig. 5) entirely lacked the throat spots; the throat was light beige with fine and faint brown central stippling (but see below). This male also had an unusual, single black nuchal-shoulder patch, which was somewhat diffuse, small, and not dissected. Other than the patch, this lizard lacked dark markings, and the dorsolateral and lateral lines were very faint. It also lacked any vivid lateral coloration. A second male (Harvard University Museum of Comparative Zoology Herpetology Observation 33, Figs. 7A \& 8A) had very narrow and widely separated patches.

We also noticed a slight metachrosis in L. lunatus (subspecies $L$. l. lunatus and L. l. thomasi) after placing live animals in enclosures. The color on the throat of one male (Harvard University Museum of Comparative Zoology Herpetology Observation 39) changed from light beige (Fig. 11A) to brown (Fig. 11B) within 10 min of being measured and photographed. Rodríguez Schettino (1999) reported no metachrosis in five Cuban Leiocephalus (unknown for L. onaneyi).

Three male $L$. l. lunatus from the Parque Mirador Sur (Figs. 6A-C), captured in order to get detailed photographs, 


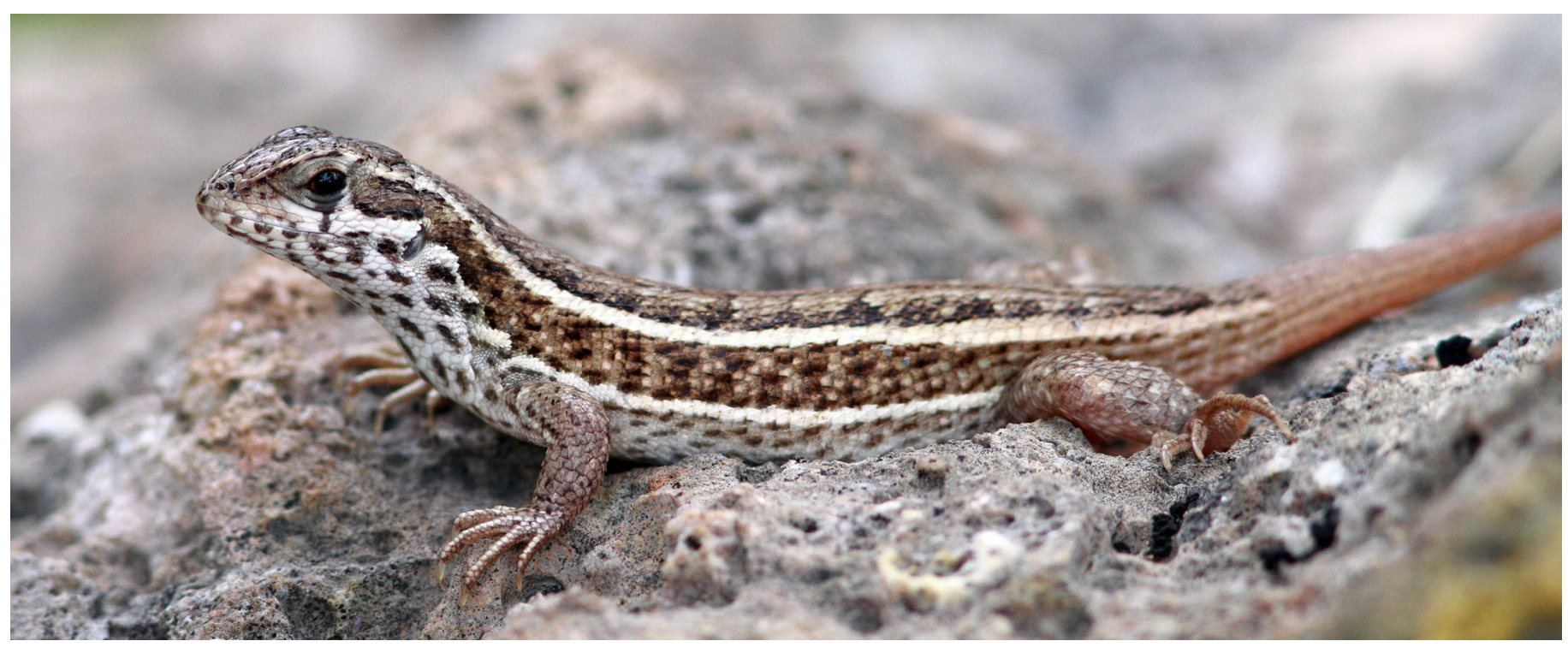

Fig. 10. An adult female Leiocephalus personatus trujilloensis (Harvard University Museum of Comparative Zoology Herpetology Observation 42). Note the lacrimal stripe and spots on the throat and venter.

were weighed and measured. All three (Harvard University Museum of Comparative Zoology Herpetology Observations 33-35) surpassed the previously known maximum SVL for the species $(67 \mathrm{~mm})$, measuring $68.9 \mathrm{~mm}, 69.8 \mathrm{~mm}$, and $72 \mathrm{~mm}$ SVL, respectively. We acknowledge that preservation can reduce specimen size, but Schwartz's (1967 and 1969) measurements were based on recently-killed specimens. Consequently, males in this population might grow to larger sizes than what had been recorded for all subspecies of $L$. lunatus. If these lizards were typical, the size difference between $L$. l. lunatus and L. p. trujilloensis in the park (maximum recorded SVL of $78 \mathrm{~mm}$ for the latter) is less than had been recorded, suggesting that competition between them might be more intense than previously thought — and could account for the apparently parapatric distributions.

Distributions.-We did not detect a contact zone between the two species in the park. An "empty" space of 1.45-1.80 $\mathrm{km}$ with no records of any curlytails separates the two species (Fig. 3). In the northern section of the park, the gap from the eastern limit of the area inhabited by $L$. l. lunatus $\left(18.43508^{\circ} \mathrm{N}, 69.98141^{\circ} \mathrm{W}\right)$ to the western end of L. p. trujilloensis range $\left(18.43871^{\circ} \mathrm{N}, 69.96823^{\circ} \mathrm{W}\right)$ is slightly narrower $(1.45 \mathrm{~km})$ than in the park's southern section (along the Avenida Cayetano Germosén), where the gap is $1.8 \mathrm{~km}$ from Calle El Diamante to the closest $L$. p. trujilloensis we found $\left(18.43832^{\circ} \mathrm{N}, 69.96475^{\circ} \mathrm{W}\right)$.

The population of $L$. l. lunatus appears to be restricted to the southwestern-most corner of the park, from Avenida Luperón to the west and Calle El Diamante to the east. We encountered the most individuals in the southern section of that area (south of Avenida Mirador Sur), and observed only a few individuals north of Avenida Mirador Sur (and all of those were in the southwestern end of that section. The area occupied by $L$. l. lunatus has a length of nearly $400 \mathrm{~m}$ (east to west), and the widest part reaches about $140 \mathrm{~m}$ (north to south).

Leiocephalus personatus trujilloensis is not limited to the Parque Mirador del Sur. It occurs throughout much of the Distrito Nacional, having been observed at the Jardín Botanico Nacional in the north and the Parque Iberoamericano in the south, and we have found individuals in the immediate vicinity of the park when we searched neighboring parks and lots. The area of the park occupied by $L$. $p$. trujilloensis ranges from the aforementioned western limits some $4.4 \mathrm{~km}$ to the Avenida Jiménez Moya at the eastern end of the park. The park does narrow toward its eastern end, and we did not survey the adjacent, highly populated Ensanche La Paz neighborhood.

Schwartz (1969) did not encounter L. l. lunatus farther inland than the strip of beach behind the type locality, and noted: "I have not taken the two species together and they retain their ecological integrity in this region. Consequently, the width of the range of $L$. l. lunatus is very narrow, perhaps in most cases less than 200 feet $(60 \mathrm{~m})$." Gali and Schwartz (1982) also commented on the allopatry of $L$. lunatus and $L$. personatus, although they stated that the two species occurred in close proximity in some parts of their ranges. These authors also discussed apparent habitat preferences, with $L$. lunatus occupying open coastal areas and L. personatus more forested areas behind the beach, indicating that "where L. lunatus occurs, $L$. personatus is not found in coastal beach areas." We also have not encountered $L$. personatus along the coast of Santo Domingo.

Not until the very end of our surveys did we locate a single male L. p. trujilloensis in the area occupied by L. l. lunatus, 


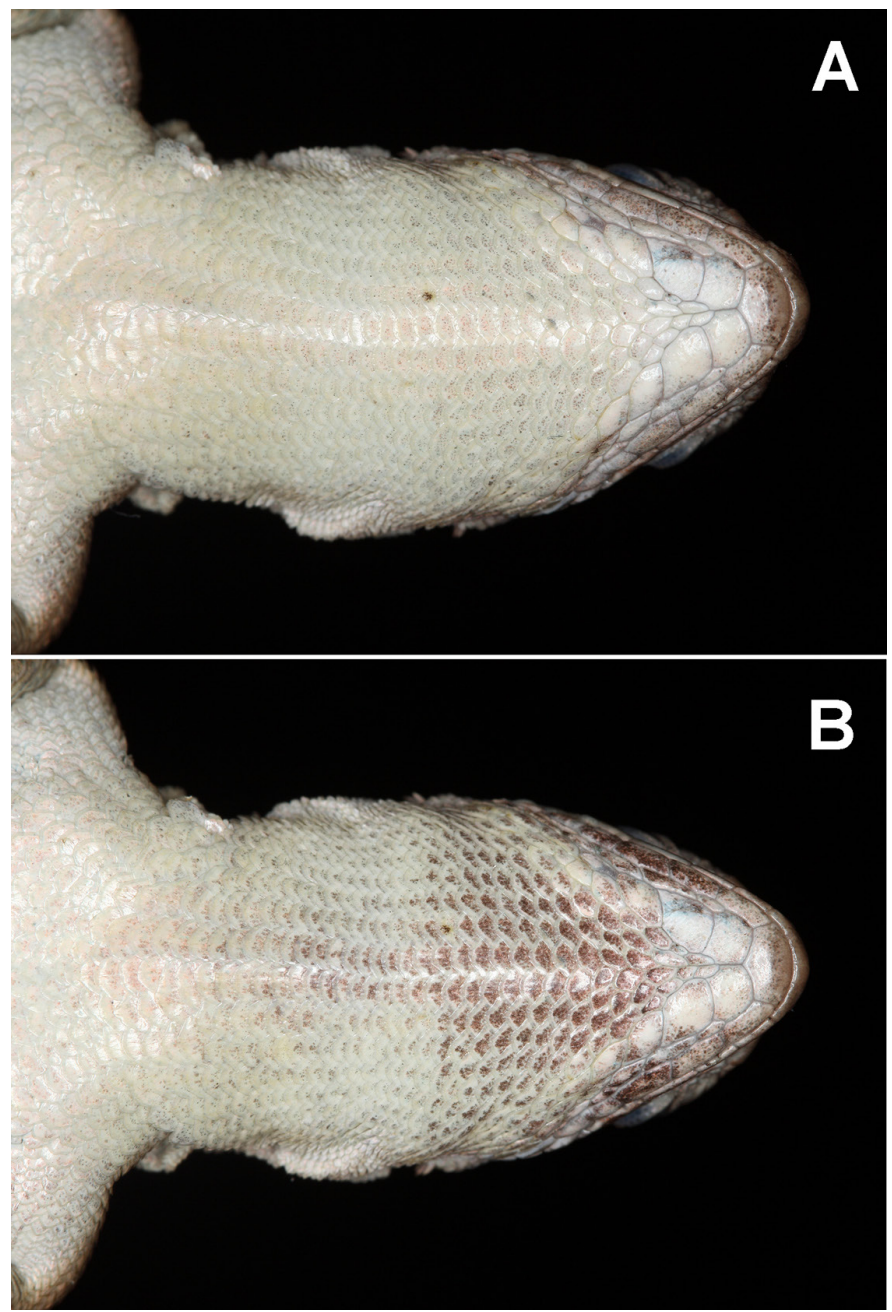

Fig. 11. An adult male Leiocephalus lunatus lunatus (Harvard University Museum of Comparative Zoology Herpetology Observation 39) with an unspotted throat. Note the change in pigmentation (metachrosis) before (A) and after approx. $10 \mathrm{~min}(\mathrm{~B})$.

surprisingly at one of the most frequently surveyed sites. This male was apparently by itself, since we repeatedly visited the spot and found no other individuals of that species. We had seen $L$. l. lunatus before at this site in the northern section of the eastern limits of its range in the park. The site is near the street and next to where we often parked. We had observed a single male $L$. l. lunatus over a period of several days in close proximity to the male $L$. $p$. trujilloensis. The usual perch of the latter was a fairly large fallen log, on which the male was quite conspicuous. We assume that the sudden appearance of this apparently isolated individual was attributable to materials being brought to the site to build a garden a short distance to the east. Days later, that individual had lost most of its tail, and eventually was not seen anymore; we suspect that predation was responsible for its disappearance.

Cochran (1934) listed the type locality of $L$. personatus lunatus (= L. l. lunatus) as "Santo Domingo City." After examining the holotype and a specimen from the type series collected at Haina and comparing those specimens with more recently collected material from west of the Río Ozama ("5.9 km W Santo Domingo, $8.6 \mathrm{~km} \mathrm{~W} \mathrm{Santo}$ Domingo, 11.2 mi W Rio Ozama”; Table 2), Schwartz (1969) restricted the type locality to what is currently known as Santo Domingo's "national district" (= Distrito Nacional), west of the Río Ozama. Schwartz (1969) also described the populations east of the Río Ozama (to Boca Chica) as L. l. lewisi. By reviewing the pertinent literature and collection databases, we confirmed that the last recorded specimens date to 1969 (Table 2). Other herpetologists who have worked in the park and elsewhere in the city have not encountered L. l. lunatus (R. Powell, pers. comm. 2017; S.J. Incháustegui, pers. comm. 2018; C. Marte, pers. comm. 2018). Recent political legislation modified and redefined the Distrito Nacional, confining it to the area bordered by the Avenida Luperón to the west and the Río Ozama to the east. However, Schwartz (1969) assigned all known specimens along this strip of coast (likely as far west as the Río Haina) to the nominate subspecies. Consequently, our observations of $L$. l. lunatus constitute the first confirmed records of the subspecies in nearly 50 years.

Activity and habitats.-Leiocephalus l. lunatus was active throughout most of the day. In the Parque Mirador del Sur, we recorded very few individuals out as early as $0700 \mathrm{~h}$ and as late as $1900 \mathrm{~h}$, both in July. Most animals were observed during the period of 1000-1700 h. In the subspecies L. lunatus lewisi, we observed a few individuals active at midday in sunny and fairly open situations. However, the habitat in the Parque Mirador del Sur of the nominate subspecies is fairly well shaded by an abundance of tall trees, particularly the introduced semideciduous Flame or Flamboyant Tree (Delonix regia), which loses its foliage almost completely during the dry season. We did not notice any bimodal activity, although at the westernmost site (west of the type locality), where we found a population at Manresa Loyola $\left(18.42344^{\circ} \mathrm{N}\right.$, $\left.70.00358^{\circ} \mathrm{W}\right)$, surveys at around $1400 \mathrm{~h}$ revealed no individuals, but when we returned at 1600-1700 h (September), we found three adult males. These were more wary than those from the Parque Mirador del Sur. Interestingly, one individual was sitting approximately $0.4 \mathrm{~m}$ high in a bush. Much of the vegetation on these coastal bluffs is comprised of dwarfed Sea Grape (Coccoloba uvifera) and Buttonwood (Conocarpus erectus), with some scattered herbaceous cover and no tall trees where the animals were found. This is quite similar to the vegetation we encountered at Boca de Yuma, La Altagracia Province, where L. lunatus thomasi was very active by $1030 \mathrm{~h}$ in sunny conditions, although those lizards were much more wary than L. l. lunatus in Santo Domingo. At $1820 \mathrm{~h}$ on the previous day, we observed very few animals and they were even more wary. Boca de Yuma lies near the easternmost tip 
of the island, and receives the first sunlight of the morning and gets only weak sunlight during late afternoon hours.

In the Parque Mirador del Sur, we observed many $L$. personatus trujilloensis active by $0915 \mathrm{~h}$ in June and as late as $1800 \mathrm{~h}$ in August, and encountered very few individuals before or after those times. Peak activity was generally between noon and $1600 \mathrm{~h}$. Some animals were in the open on rocky substrates, but most were near grasses, bushes, or trees.

During our surveys along the coast, we found active Hispaniolan Giant Whiptails (Pholidoscelis chrysolaemus) at nearly all sampled sites, but we detected $L$. l. lunatus only at the two western localities mentioned previously (Fig. 4). Mertens (1939) noted that the activity period of curlytails (referring to species in the $L$. personatus complex) is much longer than that of Pholidoscelis chrysolaemus, associating such behavior to the more passive activity (sit-and-wait foraging) of curlytails when compared to the active foraging of whiptails, with the latter reliant on warmer conditions for optimal performance.

Conservation.-Pregill (1992) suggested that species of Leiocephalus have faced a greater risk of extinction and extirpation during the Holocene than any other Caribbean reptiles except alsophiine snakes, although Hedges and Conn (2012) more recently extended that also to West Indian skinks. The principal threat to diurnally active terrestrial reptiles is predation by introduced carnivores (notably the Small Indian Mongoose, Urva auropunctata). In the Dominican Republic, only one species of Leiocephalus is considered threatened (L. altavelensis, as Critically Endangered; Incháustegui et al. 2016), whereas all species with ranges restricted to Haiti are either Near Threatened (L. melanochlorus), Endangered (L. vinculum), or Critically Endangered (L. endomychus, $L$. pratensis, L. rhutidira; IUCN 2017). In all cases, the principal causes are habitat alteration/destruction and introduced predators. Although the two species treated in this work are listed as being of Least Concern (Incháustegui and Landestoy 2016a, 2016b), some subspecies face higher threat levels. Schwartz (1969) found L. l. lunatus to be "especially uncommon," and this subspecies is likely more critically imperiled than others as it has largely disappeared from most of its range and is continuing to decline due to urban development and possible predation by cats and mongooses (Incháustegui and Landestoy 2016a). In the Parque Mirador del Sur, we frequently encountered potential predators such as chickens, rats, cats, dogs, and mongooses. Although the latter occur throughout the park, we observed them most frequently in the northern section, where we encountered the fewest lizards.

Consequently, we were somewhat surprised that the eastern Santo Domingo subspecies, L. lunatus lewisi, not only persists but is relatively common, even just across the Río Ozama (Punta Torrecillas: $18.46759^{\circ} \mathrm{N}, 69.87845^{\circ} \mathrm{W}$ ) and along the coast as far east as Boca Chica. As an explanation, we can only relate that Schwartz (1969) noted that L. l. lewisi has "a much broader inland range and a wider ecological tolerance since this subspecies occurs in scrubby fields, lowland xeric forests, and Cocos groves."

More surveys along the coastline of the Distrito Nacional are necessary to determine the current status of $L$. l. lunatus. However, the ongoing development in the Distrito Nacional has obviously isolated remaining populations and simultaneously impeded opportunities for recolonization. This narrow stretch of coastline also encompasses the very wide and very busy Avenidas 30 de Mayo and George Washington, and is regularly battered and largely inundated by storms and hurricanes. This area also would appear to be exceedingly vulnerable to rising sea levels. Consequently, any taxon restricted to such a threatened habitat must be considered threatened with extinction.

\section{Acknowledgements}

We thank Professor Angela Guerrero for assigning the final project on the subject "Ecología General 2" on Parque Mirador del Sur, for revising and offering suggestions on an earlier draft of this manuscript, and for her encouragement to turn part of the results into a publication. Bianka Sanó, Nicolás Mejía, and Yommi Piña helped in the field. Arturo León provided contacts at the Manresa Loyola from whom we requested permission to visit the site. Sixto Incháustegui, Cristian Marte, and Robert Powell shared their experiences on the localities and species that were the focus of this study. The personnel at the MNHNSD provided access to specimens in their collections. Anthony Geneva provided images of specimens of both L. l lunatus and L. I lewisi from the MCZ. José Rosado and Joseph Martínez facilitated the deposition of image vouchers at the Museum of Comparative Zoology, Harvard University (all original photography is (C) President and Fellows of Harvard College).

\section{Literature Cited}

Cochran, D.M. 1934. A new lizard, Leiocephalus personatus lunatus, from the Dominican Republic. Occasional Papers of the Boston Society of Natural History 8: 153-156.

Gali, F. and A. Schwartz. 1982. A new subspecies of Leiocephalus personatus from the República Dominicana. Journal of Herpetology 16: 177-179.

Gifford, M.E. and R. Powell. 2007. Sexual dimorphism and reproductive characteristics in five species of Leiocephalus lizards from the Dominican Republic. Journal of Herpetology 41: 521-527.

Hedges, S.B. 2018. Caribherp: Amphibians and Reptiles of Caribbean Islands (http://www.caribherp.org).

Hedges, S.B. and C.E. Conn. 2012. A new skink fauna from Caribbean islands (Squamata, Mabuyidae, Mabuyinae). Zootaxa 3288: 1-244.

Henderson, R.W. and R. Powell. 2009. Natural History of West Indian Reptiles and Amphibians. University of Florida Press, Gainesville.

Incháustegui, S. and M. Landestoy. 2016a. Leiocephalus lunatus (errata version published in 2017). The IUCN Red List of Threatened Species 2016: e.T75308752A115482971.

Incháustegui, S. and M. Landestoy. 2016b. Leiocephalus personatus (errata version published in 2017). The IUCN Red List of Threatened Species 2016: e.T75311617A115483135. 
Incháustegui, S., M. Landestoy, R. Powell, and B. Hedges. 2016. Leiocephalus altavelensis (errata version published in 2017). The IUCN Red List of Threatened Species 2016: e.T75306189A115482003.

IUCN (International Union for Conservation of Nature). 2017. The IUCN Red List of Threatened Species. Version 2017-3 (http://www.iucnredlist.org).

Köhler, G., M. Bobadilla, and S.B. Hedges. 2016. A new dune-dwelling lizard of the genus Leiocephalus (Iguania, Leiocephalidae) from the Dominican Republic. Zootaxa (4121): 517-532.

Powell, R. and M.E. Gifford. 2010. Leiocephalus lunatus. Catalogue of American Amphibians and Reptiles (872): 1-5.

Powell, R. and R.W. Henderson. 2008. Urban herpetology in the West Indies, pp. 389-404. In: J.C. Mitchell, R.E. Jung Brown, and B. Bartholomew (eds.), Urban Herpetology. Herpetological Conservation, volume 3. Society for the
Study of Amphibians and Reptiles, Salt Lake City, Utah.

Pregill, G. K. 1992. Systematics of the West Indian lizard genus Leiocephalus (Squamata: Iguania: Tropiduridae). The University of Kansas Museum of Natural History Miscellaneous Publication (84):1-69.

Rodríguez Schettino, L. 1999. The Iguanid Lizards of Cuba. University of Florida Press, Gainesville.

Schwartz, A. 1967. The Leiocephalus (Lacertilia: Iguanidae) of Hispaniola. II. The Leiocephalus personatus complex. Tulane Studies in Zoology 14: 1-53.

Schwartz, A. 1969. Two new subspecies of Leiocephalus from Hispaniola. Journal of Herpetology 3: 79-85.

Schwartz, A. and R.W. Henderson. 1991. Amphibians and Reptiles of the West Indies: Descriptions, Distributions, and Natural History. University of Florida Press, Gainesville. 